\title{
Dukuri gjuhësore të shqipes dhe ndriçimi shpirtëror i kombit shqiptar në tekste shkollore të fillimshekullit XX
}

\author{
(Hristomathi' ${ }^{1}$, në dy vëllime 1902, 1907)
}

Jorina Kryeziu (Shkreta)

Në këtë trajtesë do të ndalemi te dy vëllimet e Krestomaci²-së (Hristomathisë), të përdorura si tekste mësimore për shkollat shqipe - e bërë e ditur kjo në nëntitujt përkatës: HRISTOMATHI: gjërra të ndryshme e të vëgjejtura për këndim edhe për dobi të mësonjëtorevet shqipe... (vëll. I) dhe HRISTOMATHI: gjërra të ndryshme e të vëjejtura për këndim ndë mësonjëtoret shqipe... (vëll. II) - të përgatitura për botim nga një mëmëdhetar, Gjergj Qiriazi. Të shkruara me alfabetin e Komitetit të Stambollit e në dialektin e toskërishtes, në të

1 Tekstet janë shkruar me alfabetin e Komitetit të Stambollit. Ato mbajnë tituj e nëntituj shpjegues e të gjatë, në të cilët jepen të dhëna të detajuara:

- HRISTOMATHI: më katër pjesë - I Vjersha II Këngë III Dhiallogë IV Përalla: gjërra të ndryshme e të vëgjejtura për këndim edhe për dobi të mësonjëtorevet shqipe $A$ UDHËHEQËS PËR Ç'DO SHTËPI SHQIPËTARI - të gatuara edhe një pjesë nga dhiallogët të kthyera prej një Mëmëdhetari, Sofje, Shtypëshkronja shqipe "Mbrothësia", Kristo P. Luarasi, B-d Dmdukof N 38, 1902

dhe

- HRISTOMATHI: A UDHËHEQËS PËR Ç'DO SHTËPI SHQIPËTARI - më gjashtë pjesë - I Vjersha II Këngë III Dhiallogë IV Gjërra të-vëjejtura e vetiare V Përalla VI Gjëra të-shënuara - GJËRRA TË NDRYSHME E TË VËJEJTURA PËR KËNDIM NDË MËSONJËTORET SHQIPE të-gatuara e më të-shumatë të-përkthyera nga gjuhëra të-huaja prej një Mëmëdhetari, Sofje, Shtypurë ndë shtypëshkronjët shqipe "Mbrothësia”, Kristo P. Luarasi, 1907

2 Instituti për Studime Shqiptare dhe Protestante njofton se, në kuadër të 110-vjetorit të Kongresit të Manastirit, ndërmori ribotimin e të dyja vëllimeve të Hristomathisë, në alfabetin e sotëm e në shqipen standarde, nën titullin Krestomaci, për këtë arsye të gjithë shembujt dhe gjurmët tekstore, për lehtësi leximi e kuptimi, janë sjellë në këtë trajtesë sipas vëllimeve të cilat së shpejti do të shohin dritën e botimit, gjithashtu, kudo në artikull është përdorur titulli Krestomaci e jo Hristomathi. 


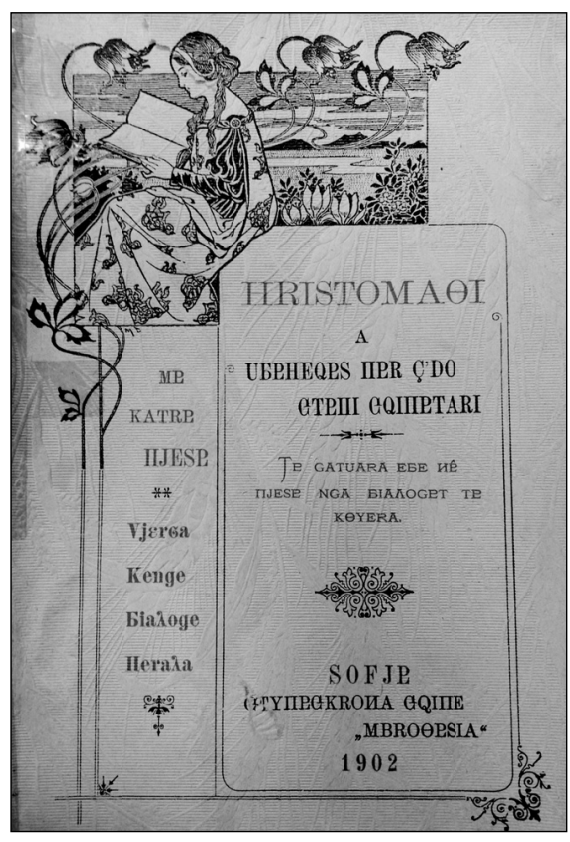

Ballina e Hristomathi, vëll. I, 1902

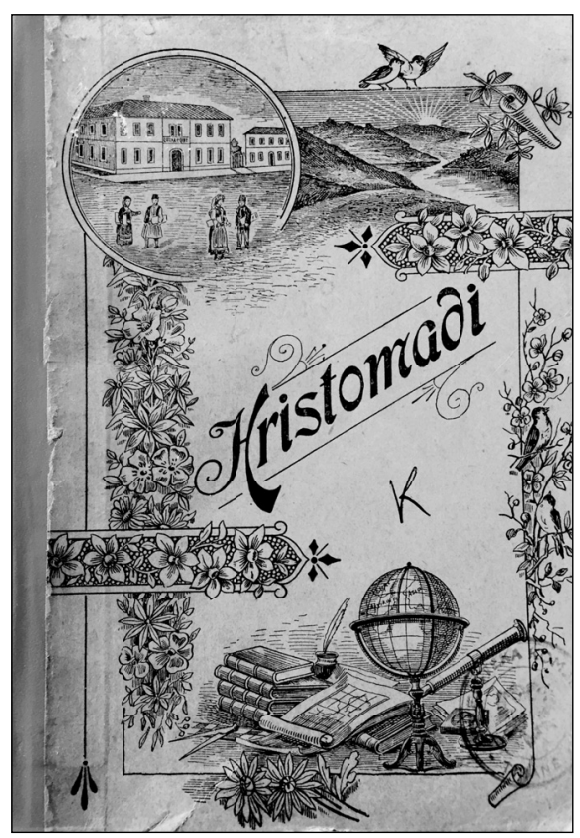

Ballina e Hristomathi, vëll. II, 1907

folmen e zonës së Korçës, këto tekste mbeten burim i pashtershëm për të vërtetuar dukuritë gjuhësore të shqipes, zhvillimin e përparimin e arsimit në gjuhën amtare dhe hartimin e teksteve shkollore prej "mëmëdhetarëve"3 - përpjekje të cilat zunë rrënjë përpara unifikimit të alfabetit shqip (1908). Sot, këto tekste mëtojnë të jenë ekzemplarë që shërbejnë më së pari për historinë e lëvrimit të shqipes së shkruar.

Vështruar në rrafsh titullor dhe përmbajtjesor, lënda e dy vëllimeve të Krestomaci-së është e larmishme, edhe pse në bosht dallohen që janë shkrime a përkthime të së njëjtës frymë, të hartuara ose/dhe të përkthyera prej Qiriazëve, të cilët kanë sjellë tituj e ndarje në secilin vëllim. Krestomacitë, përpos vlerave mirëfilli edukative, didaktike e kombëtare - si tekste shkollore - mbartin edhe vlera (të hapura) moralizuese/fetare, mbrujtur sipas doktrinës së krishterë ungjillore ${ }^{4}$ : Në duam, pra, që kisha të përmbushë

3 Një Mëmëdhetar e quan veten Gjergj Qiriazi në të dyja vëllimet, duke vënë në plan të parë jo autorësinë, por shërbimin që i bënin mëmëdheut përmes botimit dhe iluminimit të bashkëkombësve të tij, për të bërë të mundur unitetin dhe zgjimin kombëtar.

4 Shih: Hosaflook, David. Lëvizja Protestante ndër shqiptarët, 1816-1908 (disertacion doktoral, Universiteti i Tiranës, 2017), në parathënie, theksohet se: “...misionarët [amerikanë] u lidhën ngushtë me familjen Qiriazi. Disa prej fëmijëve të kësaj familjeje 


\section{Albanon}

Revistë kulturore

Pamje e zmadhuar e

shkrimit mbi derën

e godinës, ballina e Hristomathi, vëll. II, 1907

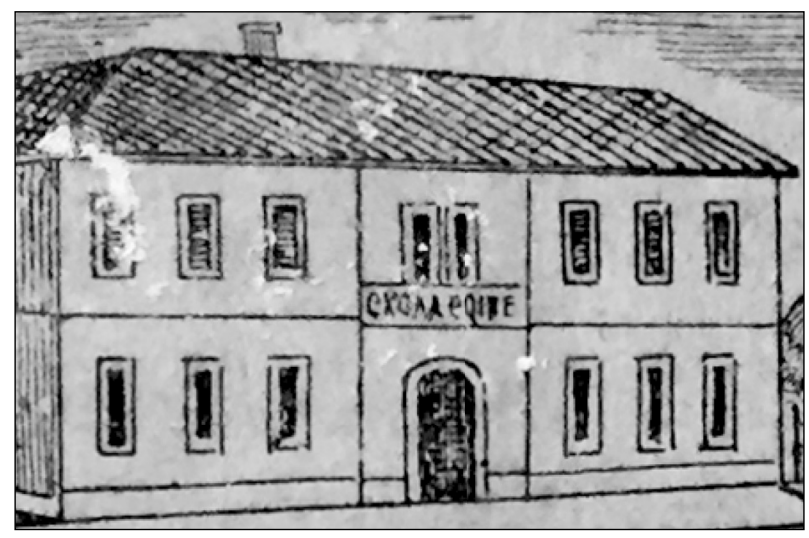

qëllimin, për të cilin e bëri Zoti, duhet tërë këndimet, urata e lavdërime qofshin këto, të bëhen në gjuhën e vendit, që t’i kuptojë bota, t’i dëgjojnë me kujdes e të ndreqen... (marrë nga pjesa Vlera e gjuhës së vet nga "Dialogë", Krestomaci, vëll. II) - në këtë fjali shprehet qartësisht përdorimi i gjuhës amë (edhe në shërbesat fetare) dhe përmes saj/kuptimit (“t’i kuptojë bota”) të arrihej ndriçimi shpirtëror i kombit shqiptar ("ndreqja").

Qysh në fazat embrionale, veprimtaria e të krishterëve ungjillorë në vendin tonë (sikurse kudo në botë) synonte arsimim (po edhe shërbesat fetare) në gjuhën amë5 (kërkonte që shkrimi i shenjtë, për t'u kuptuar, duhej lexuar a dëgjuar në gjuhën amë, në gjuhën që njeh populli), ndryshe prej veprimtarisë arsimore të feve të tjera, të cilat e zhvillonin arsimimin e shqiptarëve (po edhe shërbesat fetare) kryesisht në gjuhë të huaja, sipas rastit: arabisht, greqisht apo turqisht etj. Kështu, edhe për Krestomaci-të, është ndjekur e njëjta vijë logjike/të njëjtat parime doktrinore, siç synohej arsimimi në gjuhën amë ashtu synohej edhe ndriçimi shpirtëror i kombit shqiptar, me prirje të theksuara të krishtera-ungjillore, duke rrjedhur paralelisht e njëkohësisht të dyja parimet: iluminimi $i$ mendjes dhe $i$ shpirtit - arsimimi po dhe shërbesat në gjuhën amtare. Ravijëzohet kjo logjikë më së miri në parathëniet e Gjergj Qiriazit te Krestomaci-të, në të cilat shprehet se: “...më i madhi shërbim që mund t'i bëhet kombit tonë është t'i jepet ndonjë libër i ri në dorë, sepse faqeza duket që uria është e madhe... le të punojmë me guxim edhe pa

u konvertuan në besimin protestant-ungjillor, jo si pretekst për veprimtarinë e tyre patriotike (siç është pohuar më parë në disa artikuj në kohën e regjimit ateist), por meqë u bindën me vullnet për këtë besim". (f. xii)

5 Shih: Hosaflook, David. Lëvizja Protestante ndër shqiptarët, 1816-1908 (disertacion doktoral, Universiteti i Tiranës, 2017), f. 5, 9, 50, 55, 116, 119, 150, 162, 188, 190, 211, 213, 229, 241, 257-8, 264, 291. 
lodhje që të zbukurojmë gjuhën, sepse ajo është veriga e artë që lidh një komb dhe është më e vyera vegël për të mbrothësuarit në dituri, në urtësi, në qytetari dhe në çdo gjë të mirë që mund të lartësojë një komb” (vëll. I); "Provimi shkoqur në gjithë botët e qytetëruara ka treguar me mënyra të pakundërshtuara, se kombet gjithazi, kanë mbrothësuar e lulëzuar duke mësuar në gjuhën e tyre... i bëra [këta libra] me qëllimin e vetëm që edhe unë t’i shërbej kombit tim të dashur me sa më jepet me anë të librave për mbrothësinë e tij vetjake; se pa veti të mira e pa karakter të ndrequr çdo gjë është e kotë..." (vëll. II). Edhe personazhet e Krestomaci-së, të cilët paraqesin kryekëput pikëpamjet e Qiriazëve, shprehen për arsimimin dhe shërbesat në gjuhën amtare:

Unë shkoj në shkollën e vashave shqipe, ku mësojmë shumë kollaj çdo mësim e çdo dituri në gjuhën tonë... Tërë kombet e Evropës kishin nëpër shkollat e tyre vetëm latinishten... Po qëkur çdo komb zuri të mësohet në gjuhën e tij, fytyra e Evropës u ndryshua... Po edhe shpirtërisht kemi mbetur fare prapa me të mos pasur gjuhën të shkruar. Tërë jetën njeriu, burrë a grua qoftë, çdo të diel e çdo të kremte shkon në kishë, ku këndohen shumë urata edhe gjëra të bukura, po dru shkon e dru kthehet në shtëpi, se dëgjon një zë, po s'e kupton e as ndreqet, kur edhe ata që $i$ këndojnë, meqenëqë vetë s’ kuptojnë, shumë herë janë më të ligë nga të tjerët. Përditë këndohet Ungjilli edhe Psalltiri [Psalmet], edhe shumë njerëz i dinë ata prej goje, po ç'dobi kanë nga kjo, kur si kuptojnë... (marrë nga pjesa Vlera e gjuhës së vet nga "Dialogë", Krestomaci, vëll. II).

Përqasur nga pikëpamjet përmbajtjesore, tipologjike e kuptimore mund të themi se në të dyja vëllimet e Krestomaci-së dallohet raporti jo vetëm tematik religjion/komb. Shkrime me karakter religjioz, me citime të plota të vargjeve nga Dhiata e Re dhe nga Dhiata e Vjetër, ka gjerësisht në të dyja vëllimet e Krestomaci-ve, përkatësisht nga: Zbulesa, Eksodi, Psalmet, Fjalët e urta, Hagai, Ungjilli sipas Mateut, Ungjilli sipas Markut, Ungjilli sipas Gjonit, Veprat e apostujve, Efesianëve, Kolosianëve, Korintasve (I dhe II), Romakëve, Hebrenjve, Timoteu (I dhe II) etj. Prania koherente e frymës së krishterë ungjillore, me referenca nga shkrimet e shenjta biblike, i pozicionon këto vëllime si tekste të shkollave, ku përveç anës didaktike, mësohej edhe doktrina fetare: "Aty përpara dëgjova mësuesen të thotë se njeriu duhet të kërkojë përditë urtësi nga Zoti, sepse vetëm kështu mund t’i bëjmë shtëpitë tona të lumtura." [referoju edhe nëntitullit "udhëheqës për çdo shtëpi shqiptari”] (marrë nga pjesa Pas shkollës, nga "Dialogë”, Krestomaci, vëll. I). Gjithashtu, mund të 


\section{Albanon}

\section{Revistë kulturore}

mendohet se fryma religjioze, që mbizotëron dendur në këto tekste, mund të jetë një prej arsyeve përse ato janë lënë thuajse në errësirë gjatë periudhës moniste:

Tani kuptoj se ëmbëlsia e jetës fshihet në të bindurit e fjalëve të urta të Zotit, edhe se më $i$ madhi qëllim $i$ jetës sonë lypset të jetë që ti përgjigjemi qëllimit, për të cilin Zoti na krijoi, domethënë të lavdërojmë emrin e Tij. Njeriu rron në këtë botë, jo për veten e tij, po për të tjerët. A do të jesh e ngopur nga jeta në këtë botë? Bëj mirësinë, duaj të aférmin si veten, duaj armikun, puno për kombin me urtësi për ti sjellë ata në rrugë të drejtë. Kjo është lumturia më e madhe që mund të ketë njeriu në botë. Kjo lumturi do ta përgatitë njeriun që të jetë edhe trashëgimtar i jetës së pasosur. (Marrë nga pjesa Pas shkollës, nga "Dialogë", Krestomaci, vëll. I.)

Vëllimet e Krestomaci-së janë përdorur si tekste mësimore, por në to gjejnë vend vetëm pjesët e përzgjedhura ose të përkthyera, pa u shoqëruar me aparate pedagogjike apo dhe citime të burimeve prej nga është vjelë lënda, përjashtim bëjnë këtu citimet biblike, por edhe këto të fundit nuk janë bërë të ditura për secilin rast. Pjesët e përfshira në Krestomaci-të I dhe II mund të jenë përdorur si ushtrime leximi, në të cilat dallohet një kombinim funksional për secilën ndarje ("pjesë" apo "copë" siç parapëlqen t’i quajë autori/hartuesi), disa prej të cilave janë shoqëruar edhe me shënime nga autori i tyre:

Vëllimi I (1902) është ndarë në katër pjesë, përkatësisht: I Vjersha, II Këngë, III Dialogë, IV Përralla, - gjëra të ndryshme e të vlefshme për këndim edhe për dobi të mësonjëtoreve shqipe;

- Vëllimi II (1907) është ndarë në gjashtë pjesë, përkatësisht: I Vjersha, II Këngë, III Dialogë, IV Gjëra të vlefshme e vetjake, V Përralla, VI Gjëra të shënuara - gjëra të ndryshme e të vlefshme për këndim në mësonjëtoret shqipe.

Gjatë analizimit të përmbajtjes së këtyre dy vëllimeve, nga titulli në titull e nga pjesa në pjesë kemi dalluar se ato janë hartuar në bazë të disa kritereve kryesore, siçjanë: kriteri edukativ e didaktik, kombëtar, didaktiko-moralizues/ fetar, mirëfilli fetar, informativ etj., përmes syresh synohet që nxënësit e shkollave, po dhe shqiptarët në përgjithësi (nëntitulli "udhëheqës për çdo shtëpi shqiptari”) të arrijnë qëllimet arsimore dhe fetare përmes arsimit në gjuhën amtare, të zhvillojnë identitetin e tyre vetjak, kombëtar e fetar, të përvetësojnë njohuri e vlera kulturore e qytetare, të zhvillojnë përgjegjësi të ndryshme etj. Mbështetur në këto aspekte kemi bërë një përndarje të 
pjesëve të përfshira në këto dy tekste shkollore. Duhet theksuar se kjo ndarje e shkrimeve ose dhe përkthimeve të Krestomaci-ve nuk është përcaktuese, por synon të mbetet thjesht orientuese për lexuesin.

\section{- Kriteri edukativ e didaktik:}

K I: I. "Vjersha”: Ç’bëri një çupë në Filadelfia t' Amerikës, Përtimi, Merimanga dhe flutura, Shoqe të mira, Gëzimi, Plaku edhe Miti;

II. "Këngë": Cinglash, Lamtumirë o shkollë, Zogu, Provimet, Dituria, Koha po shkon, Ecën fort gëzuar, Dit' e gëzuar, Provimet;

III. "Dialogë": Kur do të bëhemi nëna?, Rrobat e Olimbisë, Secili ka vlerën e tij, Të shkruarit e babait, Kulaçi, Të pastruarit, Sa qëndron një e mosshkuar në shkollë, Drita, Efshehta, Përse u zbardhën flokët e gjyshes?, Dy mënyra të të parit të një gjëje, Numëro njëqind, Dashuria e bashkënxënëseve, Trumba, Lustrat, Shkolla, Dashuria e vërtetë, Pija, Ç'bëtë sot?, Shkolla, Smira (nakari), Ç’do të bëjmë kur të rritemi?, Përgjuesja, Shkruesja e dëshpëruar, Mësimi do dashuri, Madhështorja, Pyetjet, Llomotarët, Të dymbëdhjetë muajt, Pushimi i humbur, Ha që të rrosh, e mos rro që të hash, Të sharat, Filozofia e të miturve, Nderi dhe argjendi, Arsimi;

IV. "Përralla": Djalëria edhe pleqëria, Dashuria për mëmëdhenë, Të tria kunatat, Fjalë të mira, Të dëgjojmë më të mëdhenjtë, E drejta, Ndihmoji vetes, E lagu s'e lagu etj.;

K II: I. "Vjersha”: Kishte a s'kishte kokë, Dimri edhe vera;

II. "Këngë": Qetësia e detit edhe e valëve, Vlera e kohës, Cigarja, Sepse më duan!, Edhe se është e varfër! Vajza që do të duket, Të prishurat për giyqin, Pësonjësi shëronjës;

IV. "Gjëra të vlefshme e vetjake": Dobia e shtrëngimeve, Sjellje të mira, Dashuria për mësimin, Papa Adriano, Varfëri me të dashur, Një plakë e varfër, Një argjenddashës i çuditshëm, Filopimeni, Një shtëpi përuljeje, Të tërhequr nga madhjet në plaçkat e shtëpisë, Të tërhequr nga madhjet në rrobat e trupit, Stolia e ushtarit, Gurët e paçmuar të një nëne, Të ngrënët me masë, Jeta pa të tepërta, Mospërmbajtja, Të dehurit, Sjelljet e një djali pesë vjeç, Të zgjedhurit e shoqeve, Koha është flori, Bashkëfolja;

VI. "Gjëra të shënuara”: Trimëria e një vajze, I vogli këpucëpastrues, Sokrati edhe Llambrokliu, Zemra e dhimbsur e një muzikanti, I vogli Pier (Pjetër), Dashuria udhëheqëse, Të mirën në vend të së ligës, Si një anglez i fisshëm e shpëtoi një mace, Qëndrimi etj.; 


\section{Albanon}

\section{Revistë kulturore}

- Kriteri didaktiko-moralizues/fetar, të mbrujtura nën doktrinën e krishterë ungjillore

K I: I. "Vjersha”: Dituria, Të dyja fjalët, Pianiku, Shtëpia e pianikut, Shtëpia e gëzuar, Druri i Krishtlindjeve, Dituria e vërtetë, Shkolla, Djali i verbër, I verbri dhe i çali, Zemërimi, Tërmetet e Korçës, Gjyqi i drejtë, Urim, Shpagimi i mirëbërësit, Djali i varfër, Detyra të mira, Çupa e varfër, Çupa trime, Bariu i mirë, Margaritarja, Gjendja e pastajme;

II. “Këngë”: Zëri i shkollës, Koha, Dita e pushimit, Pianiku, Lul' e bukur, Nëna e varfèr, Djali i varfér, Çupa e varfér, Provimet, Bariu, Nën' e helmuar, Pas provimit, Nënë e harruar;

III. “Dialogë”: Rrobat e mira, Përse frutat bëhen të ëmbla nëpër drurë?, Shpresa edhe durimi, Njeridashja, Provimet, Zëri i shkollës, Vlera e diturisë, Ç’është fshehtësia e jetës së lumtur, Pas shkollës;

IV. “Përralla”: Si të bëhemi tëpasur, Zëri i ndërgjegjes, Dëshmim i përbrendshëm);

K II: I. "Vjersha”: Lulja, Shtëpia pa nënë, Vlera e urtësisë, Njerëzit do të flasin, Si shkove tatëpjetë djali im!;

II. "Këngë": Ditët e djalërisë;

III. “Dialogë”: Vajza përdëllimtare, Që në vogëli do mësuar e mira, Armiqësia mes së mirës e së ligës, Lakmitarja, Thesaret e urtësisë, Më e mira dhuratë;

IV. "Gjëra të vlefshme e vetjake”: Ndërgjegjja e mirë edhe ndërgjegija e ligë, Të përpjekurit me guxim e me durim, Të metat duhen shkulur posa kuptohen, Një rrugë për të mbrothësuar në mirësi, Një e metë u njoh edhe u ndreq, Prishja edhe Mendimi, Zilia edhe Nakari, Shoqëria e mirë, Shoqëria e ligë, Frytet e këqija të shoqërive të liga në vogëli, Korbi i ngordhur, Vlera e punës së mirë, E vërteta, Madhështia, Më i miri shpagim, Të falurit përmbi të luajturit me letra, Paga e fajit, Ç’i sollën Margaritës Krishtlindjet etj.;

\section{- Kriteri mirëfilli fetar:}

K I: I. "Vjersha": Perëndia edhe vdekja, Urtësia edhe dituria, E para dit' e majit;

II. "Këngë": Zoti ndihmës, Ndjesë edhe paqtim, Pija, Hidhni litarin, Të falurit e një çupe trime, Aleluja, Këng’ e foshnjave në djep, Triflli, Himn, Ngushëllim për të helmuarit, Zë nga Sioni;

III. "Dialogë”: Bekimet e shkollës, Kundërfolje: A mund të sjellë mirësi në botë Dituria pa Ungilll?, Syri i Zotit shikon kudo; IV. "Përralla”: Jusufi) etj.; 
K II: II. “Këngë”: Mirë se erdhët, Drejtësia mbretëron, Dyert e hapura, Një gojë; Zëri i të vdekurve;

VI. "Gjëra të shënuara”: Emri i Jezu Krishtit, Ka Perëndi, Një tregim i shkurtër i atyre gjërave që na mëson Shkrimi i Shenjtë, Të falurit, Dëshmorët e krishterimit, Thelbi i urtësisë së hindasve, Detyrat e burrit e të gruas, E pesta porosi: "Mos vrit!" (Eksodi 20:13), Mendohuni për udhët tuaja (Hagai 1:5), Fundi i shoqërisë së mirë edhe fundi $i$ shoqërisë së keqe, Lumturitë) etj.;

\section{- Kriteri kombëtar:}

K I: II. "Këngë": Dituria, Shqiponja, Dituria, Vlera e diturisë, Detyrat e mëmëdhetarit të vërtetë, Zë nga dheu $i$ huaj, Gjendja e pastajme, Dashuria e mëmëdheut;

III. “Dialogë”: Një rrugë në Shqipëri, Shoqëria "Dituri”;

IV. "Përralla": Lindja edhe profecia për Skënderin) etj.;

K II: Fare pak të karakterit kombëtar: III. “Dialogë”: Vlera e gjuhës së vet etj.

\section{- Kriteri informativ:}

K I: përfaqësuar vetëm nga një shkrim: Pitagora (IV. "Përralla") etj.;

K II: Iv. "Gjëra të vlefshme e vetjake": Arsimi, Bariu i Etrikut, Efklidhi, Petrarka, Platoni, Zonja Dacier, Bernadoti në Vjenë, Sinsinati, Teofilakti, Prensi kopshtar, Nublej, Shtëpia e Zhanë d'Ark (1817), Dëvej (Davy), Si një vajzë u shqua;

v. "Gjëra të shënuara": Një ngjarje e Galileos, Puna edhe durimi janëfshehtësitë e mbrothësisë, Arkimedi, Galileo, Gutenbergu, Livingstoni) etj.;

- Anekdota: KI: (te IV. "Përralla");

- Fjalimet e Sevasti Qiriazi-Dako: K I: (te IV. "Përralla”). Në mbyllje të viteve shkollore, në Mësonjëtoren e Vashave në Korçë, Sevasti Qiriazi-Dako mbajti fjalën e saj, të titulluara në KI, Fjalë: Zonja edhe zotërinj, të përfshira në pjesën e fundit të librit, te "Përralla" - zgjedhje e autorëve kjo.

Përmbledhtazi e jo prerazi, do të thoshim se vëllimi i parë përmban më së shumti shkrime të karakterit: edukativo-didaktik, kombëtar dhe moralizues/ fetar, të mbrujtura nën doktrinën e krishterë ungjillore; ndërsa, në vëllimin e dytë, veç kritereve të lartpërmendura, çuditërisht, shkrimet e karakterit kombëtar janë fare pak, madje edhe pjesa Vlera e gjuhës së vet, është e mbrujtur sipas pikëpamjeve të doktrinës ungjillore: Andaj shumë e madhe marrëzi është 


\section{Albanon}

\section{Revistë kulturore}

t’i falemi Perëndisë me një gjubë që s’e kuptojmë, sado e mirë, e lartë, e bukur që të jetë kjo. Edhe shpirtërisht, pra, simund të kemi mbrothësi pa gjuhën tonë... (marrë nga pjesa Vlera e gjuhës së vet nga "Dialogë”, Krestomaci, vëll. II.). Në vëllimin e dytë, shkrimet e karakterit moralizues/fetar janë më së shumti në pjesën e fundit "Gjëra të shënuara", e cila, për nga volumi, përbën gjysmën e librit.

Në të dyja vëllimet e Krestomaci-së, në raste të veçanta, është ndjerë mungesa e një leksiku konkret të shqipes, çka ka bërë që autorët të vendosin mes kllapave, veç fjalës shqipe, edhe fjalën e huaj, në frëngjisht, greqisht a anglisht, çka shërbejnë si një busull për të na orientuar për gjuhën prej nga është përkthyer shkrimi përkatës - mbështetur kjo në nëntitullin që shoqëron vëllimet: Të përgatitura e një pjesë nga dialogët të përkthyera (I) dhe Të përgatitura e më të shumtat të përkthyera nga gjubë të huaja (II). Përdorime të tilla, po dhe trajta më të vjetra të shqipes, gjenden edhe në vëllimin II (1907), çka na mundëson një tjetër qasje mbi kronologjinë e shkrimeve që gjenden në këto vëllime, edhe pse vëllimi I është më i hershëm si vit botimi. Pra, edhe disa prej shkrimeve të vëllimit të dytë mund t’i përkasin Gjerasim Qiriazit.

Në Krestomaci I dallojmë shenja të qarta gjuhësore, jo vetëm të rrafshit leksikor, për shkrime më të vona se ato të Krestomaci II, të cilat mund të jenë, siç u lartpërmend, të kohës së Gjerasimit apo vetë atij. Për ilustrim përmendim këtu disa fjalë, që përdoren në një trajtë më të hershme te Krestomaci II sesa te Krestomaci I, si për shembull: kombëtar:e (I) - kombiar:e (II); për të shquarën turpi (I) - turpja (II); kursar (II) - kusar (I); dhiplomë $(\delta i \pi \lambda \omega \mu \alpha)$ për diplomë (I) - dëftesë $(\delta i \pi \lambda \omega \mu \alpha)$ (II); fjala dhuratë del vetëm tek I (por përdoret edhe në trajtën dhurëti), ndërsa te II përdoret vetëm në trajtën dhurëti; mosha (po dhe vërsë) te I, ndërsa vërsë te II; fjala letër del te I, ndërsa kartë te II; pansion (I) - nxehtësirë (II); kalorës (I) - kalëtar (II); dhe anasjellas, fjalë më të reja te Krestomaci II krahasuar me Krestomaci I, çka vërteton se disa prej shkrimeve që gjenden në të mund të jenë të njëkohshme me kohën e botimit, si për shembull: fjala mbrothësi del edhe në trajtën përparim te II, ndërsa te I vetëm në trajtën mbrothësi; fjala shëronjës del edhe në trajtën mjekës te II, ndërsa vetëm shëronjës te I; fjala qiellshkrues del edhe në trajtën astronom te II; astronomi (I) - qiell-shkronja (II) etj.

Në të njëjtën mënyrë, në botimin e vitit 1902, nga njëra anë, dallojmë se ka fjalë që janë gjendur me vështirësi, e për këtë, fjala është shoqëruar edhe me gjegjësen e saj të huaj; dhe, nga ana tjetër, hasen fjalë të reja (neologjizma), të përzgjedhura me finesë e nuhatje gjuhësore, siç janë: 
- fjalë të formuara me anë prapashtesash

K I: sëmurëtore - për spital (<sëmurë + tore), ditëtore - për ditore/gazetë e përditshme (<ditë + tore), shitëtore - për dyqan $(<$ shitë + tore $)$, nakartare $(<$ nakar + tare $)$, skllavos - për skllavëron $(<$ skllav + os $)$ etj.;

K II: lulore - vend për lule $(<l u l+$ ore $)$, lajtare - vaskë $(<l a j+$ tare $)$, endar endës $(<e n d+a r)$, kalëtar - kalorës $(<k a l+\ddot{e} t a r)$ etj.;

- fjalë të formuara me anë prapashtesash e prapashtesash njëherazi

K I dhe K II: p.sh. te $H$ II, ndërpërshkuarshim - i tejdukshëm (<ndër + për + shkuar + shim) etj.;

- fjalë të formuara nga përbërja ose përngjitja

K I: mirëveti - për virtyt (mirë-veti), varfërë-ushqenjëtore (<varfërë-ushqenjëtore), dorë-shkronja - për dorëshkrim (dorë-shkronja), detnotës - për detar (det-not-ës), barrë-sjellës - për hamall (barrë-sjell-ës), rrobë-qepësja - për rrobaqepësja (rrobë-qepës-ja) etj.;

K II: këmbanë-qëndresë - kambanore (këmbanë-qëndresë). bashkërresht regjiment (bashkë-rresht), burgruajtës - gardian (burg-ruaj-tës), dhebaritës po dhe dheshëtitës - eksplorator (dhe-barit-ës/ dhe-shëtit-ës), ngrohtëmasje termometër (ngrohtë-mas-je), qafélidhje - kravatë (qafë-lidh-je), gjithëshitje - dyqan (gjithë-shit-je), huajpritje - han (buaj-prit-je), huajpritës - hanxhi (buaj-prit-ës) etj.;

- falë të formuara nga nyjëzimi ose dhe prapashtesat zvogëluese

K I: të bukurazë (të bukura-zë), të dhelpërisë (të dhelpëri-së) etj.;

K II: $e$ kashtë - prej kashte, ndjenja të njerinjta - njerëzore (nyjëzim + prapashtesim) etj.;

- neologjizma "purike":

K I: Dhemasje - për gjeometri, Dheshkronjë - për gjeografi, dorë-shkronja për dorëshkrim, Njeri-tregonjë - për fiziologji etj.;

K II: dhebaritës/ dheshëtitës - për eksplorator, Dhemasje - për gjeometri, Dheshkronjë - për gjeografi, ngrohtëmasje - për termometër; Qiellshkronjë astronomi etj.;

Veç mënyrave fjalëformuese, pasurimit të gjuhës me fjalë të vetë shqipes purizmi gjuhësor $i$ rilindësve - të cilët linin jashtë përdorimit huazimet e çdo lloji, në këta libra gjejnë vend shumë dukuri të tjera gjuhësore, që synojmë të jenë ngasje për të ngjallur interesin e studiuesve apo gjuhëtarëve, ndër të cilat 


\section{Albanon}

\section{Revistë kulturore}

do të përmendim disa syresh, për të vërtetuar me gjurmë tekstore sesi kanë evoluar disa trajta të shqipes së para një shekulli në trajtat e shqipes së sotme:

- rasa vendore (lokativi)/zhdukja e saj sot

Krestomaci I (1902): ndë botët, ndë qytett, ndë skolit, ndë udhët, ndë shtëpit, ndë kopshtt, ndë asheft, ndë deret, ndë murt, ndë mërshët, ndë kupët, ndë govatët etj.; e formuar nga parafjala $n d \ddot{e}$ dhe mbaresa $-t$ );

Krestomaci II (1907): ndë xhept, ndë shtratit, ndë syt etj.; e formuar nga parafjala $n d \ddot{e}$ dhe mbaresa $-t$ ); mbaresat rasore (p.sh., kallëzorja -në, në shqipen e sotme në shumë raste përkojnë me: -in/-un etj.);

- rasa thirrore/zhdukja e saj sot

K I dhe K II: vendosja e frazës në thirrore kryesisht në fillim të fjalisë: $\hat{O} e$ marrë! (H I) etj.;

- disa mbaresa rasore

K I dhe K II: p.sh. te $H I$, rrahnë, vdiqnë etj., pra kallëzorja e formuar me mbaresën -në) etj.; formimi i rasës kallëzore në shqipen e sotme në shumë raste përkojnë me: -in/-un/-ën; pra kallëzorja e formuar me mbaresën -në) etj.; formimi i rasës kallëzore në shqipen e sotme në shumë raste përkojnë me: $-i n /-u n /-\ddot{e} n$

- mjetet e formimit të shumësit (sidomos me mbaresën -ra)

K I dhe K II: p.sh. te $H$ I, ngjyrëra, marrëzira, bukurira, punëra, skolirra, shtëpira, çudira, kotësira, lumërira, bishëra etj.;

- ndryshimi i gjinisë së disa emrave të sotëm nga femërorja në mashkullore dhe anasjellas

K I: p.sh.: parajsi për parajsë, surprizi për surprizë, sholli për sholla, barbarisma për barbarizmi, egoisma për egoizmi, frushkulle për frushkulli, kulaça për kulaçi, shëmbëlla për shembuj, zakonet e vjetërë për zakonet e vjetra etj.;

K II: p.sh.: një shëmbëllë më të-madhe për një shembull më i madh, siekëlla të-hekurta për shekuj të hekurt etj.;

- përdorimi i cezurës

K I dhe K II: përdorimi i cezurës në të dyja vëllimet, por hasim një përdorim më të dendur të saj te vëllimi II edhe pse botimet i ndan një hark i shkurtër kohor (5-vjeçar), çka tregon se interesimi i gjuhës, çështjeve gjuhësore ishte prioritar ndër rilindës;

- mënyra e formimit të: 


\section{- foljeve}

K I: përdorimi i pjesëzës $u$ me cezurë ose dhe me trajtën e shkurtër të përemrit vetor: u-dashkërka, u-poqmë, u-bëra, u-hidhëro, u-gjende etj.; përdorimi i cezurës dhe i trajtave të shkurtra të përemrave: përdëlle-na, fal-na, afro-na, ndih-na, trego-na, thua-na, shiko-na etj. (na: trajtë e shkurtër e përemrit vetor $n e)$, bëj-më, dëgjo-më, lër-më, thua-më etj. (më: trajtë e shkurtër e përemrit vetor të vetës së parë, numri njëjës), këto trajta të shkurtra përdoren pas foljes me cezurë, për të treguar afërsinë apo dashamirësinë e folësit: dëgjo$m \ddot{e}-n i$, lër-më-ni, beso-më-ni, trego-na-ni etj.; përdorimi i cezurës te lidhorja: të-prerë, të-helmuarë etj.);

K II: përdorimi i cezurës dhe i trajtës së shkurtër të përemrave: trego-na, vërna, rrëfe-na etj. (na: trajtë e shkurtër e përemrit vetor ne), rrëfe-më, trego-më etj. (më: trajtë e shkurtër e përemrit vetor të vetës së parë, numri njëjës), këto trajta të shkurtra përdoren pas foljes me cezurë, për të treguar afërsinë apo dashamirësinë e folësit; përdorimi i cezurës te lidhorja: të-prerë, të-helmuarë etj.;

- përemrave (me apostrofim, cezurë etj.)

K I: s'anë, t’ona, sonë, t’ënd, i-cili, e-ti, e-mi, të-këtillë, të-tjerë, tjatri, as-gjë, tynë, gjithë-kush, ç'do farë etj.;

K II: s’onë, tona, tënt, të-cilënë etj.;

\section{- mbiemrave}

$K$ I: mbiemrat e nyjshëm: përdorimi i cezurës ose dhe $\ddot{e}$-së fundore: të-reja, të-mirë, e-shkurtërë, e-vogëlë, $i$-verdhur, i-helmuar etj.; mbiemrat e panyjshëm: përdorimi i cezurës: mirë-bërës, kokë-trashë, mendje-holla, fat-zinjtë, zëmërëkthiellëta, zëmërë-dhëmçurë etj.;

K II: mbiemrat e nyjshëm: përdorimi i cezurës ose dhe $\ddot{e}$-së fundore: $e$-mesme, të-vogëla etj.;

- ndajfoljeve (sot përdoret shpesh përngitja)

K I: mbë nj' anë (për mënjanë), an’ e mb' anë (për anembanë), gjith' ashtu, gjithë-një, po-thua, për-dita, ndonjë-herë, nga ndonjë-herë, nga dalë, tej-për-tej, pak-së-paku, pas-këtajthi, sa-kaqë-herash, për-një-herësh, kur-do-herë, do-methënë, fshehuraj, do e mos, që kur, as fare etj.;

K II: ndonjë herë, nga ndonjë herë, sa-kaqë-herash, për-një-herësh, do-me-thënë, fshehuraj etj.;

- numërorëve (me apostrofim, cezurë etj.) 


\section{Albanon}

\section{Revistë kulturore}

K I dhe K II: p.sh. te $H$ I, pesë-mbë-dhjet', një-zet', një-zet' e pesë, tri-dhjetë e pesë, një-qind, një mijë e katër-qind etj.;

\section{- prapashtesave përkëdhelëse ose zvogëluese}

K I: -ck(ë)a: koteckë, këpucka, nënocka; -ckël: i-vockëlë; -cë: kallogricë; -zё: vetëzë, dashurizë, diturizë, shpirtëzë, shkëndijëzë, pakëzë, rakizë, bukëzë, druzë, shtëpizë, parazë, rublëzё, njëzё (për nёjsh - vlerësimin në notë), farëzë (për zero - vlerësimin në notë); -za: mëmëza, shoqeza, syzeza, fletëza etj.;

K II: nënoçka, pakëzë, farëzë etj.;

- lidhëzave/ lokucioneve lidhëzore (me cezurë etj.)

K I dhe K II: p.sh. me-qënë-që, sikur se, si kundre, që kur se, përveç se etj.;

\section{- parafjalëve}

K I dhe K II: p.sh. mbë për më, në shqipen e sotme në shumë raste është shndërruar në në etj.;

- bashkëtingëlloret nistore ç-, xh- në vend të sh-së, zh-së

K I: çpërblim, çpuanë, e-xhveshurë, çkulnjë, çqaurë, çfaqurë etj.;

K II: çkëlqim, çkëmbimi, çpejtim, çfaqurë etj.;

- ̈̈-ja fundore apo përdorimi i apostrofit në vend të saj

K I: dit, fuqin', jetën', bishtin' etj.;

K II: të-vogëlë, këshillën', kishinë, vendin' etj.;

- përdorimi i zanoreve të theksuaral theksi

KI: thirrori $\hat{o}$; mendó, edhé, átë, këto, ató, pecé, diturí, rrî, mirësi, mundim, pô, sýzëza etj.; po dhe te trajtat e shkurtra: tả, mả, jả, uả etj.;

KII: mbretëró, dhé, pará; po dhe te trajtat e shkurtra: tả, mả, jả etj.;

\section{- pikësimi, rendi i fjalëve në fjali}

K I dhe K II: përdorimi i dendur i anasjellës etj.

Këto dukuri po edhe shumë dukuri të vjetra gjuhësore gjejnë përdorim në këto vëllime.

\section{- formimi i emrave të përveçëm:}

K I: (prej huazimeve greke, për shembull: bashkëtingëllorja $v$ derivate e $b$-së ose $u$-së (sipas rastit) apo bashkëtingëlloret dyshe (bigrame/digrafe) $d h, l l$, th janë derivate të $d, l, t$ etj.)

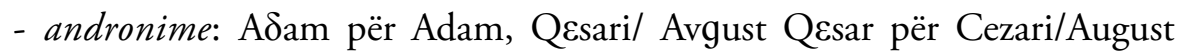


Cezar, Elisaveta për Elisabeta (mbretëresha), Iisu-Kriøti për Jezus Krishtin,

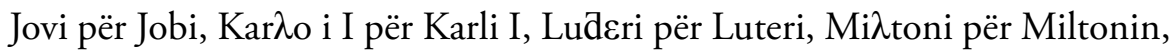

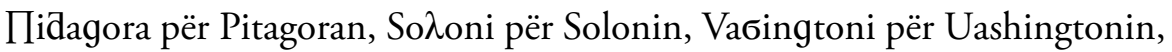
Ysufi për Jusufin, Ati Ibrahim (për Abrahamin), su $\lambda \tan A b d u \lambda$ Hamit Han te II $^{\text {-te }}$ për sulltanin Abdyl Hamit Hani II, Skender për Gjergj Kastrioti Skënderbeu etj.;

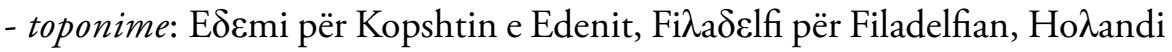
për Holandë, Гinokastre për Gjirokastër etj.;

K II: (prej huazimeve greke, për shembull: bashkëtingëllorja $v$ derivate e $b$-së ose $u$-së (sipas rastit) apo bashkëtingëlloret dyshe (bigrame/digrafe) $d h, l l, t h$ janë derivate të $d, l, t$ etj.)

- andronime: Avel për Abel, Avraam/Avrahami për Abram/Abrahami,

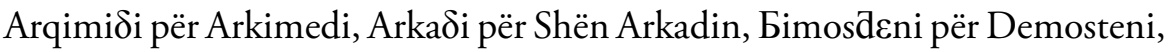
I $\lambda$ i për profetin Elia, Enoh për Enokun, Joan Пagezimtori për Gjon Pagëzorin, Joannese Ark për Zhanë d'Ark, Пavli për Shën Palin, Ioani/Joani/Joanni për Shën Gjonin, Ange për Hagain, Omiri për Homerin, Iisuj-Kriбti për Jezus Krishtin, Jovi për Jobin, Jakovi për Shën Jakobin, Kistofor-Koגombi për Kistofor Kolombin, Luder për Luterin, Montєsqiu për Monteskjenë, Nyton për Njutonin, Пana Adrianoj për Papa Adriano (VI), Пana Urvanoj për

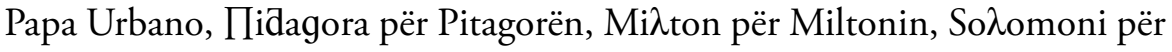
Solomonin, $\Pi \lambda$ atoni për Platonin, $\Pi \lambda u$ utarku për Plutarkun, Marq $\varepsilon \lambda i$ për Markelin, Qiri $\lambda$ për Kirilin, Cincinati për Sinsinatin, Tito Livioj për Tit Livin, Vaбington për Uashingtonin, etj.;

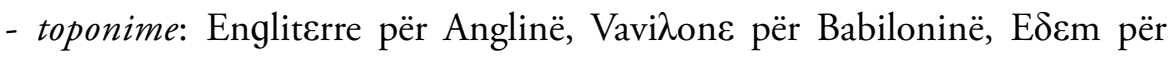

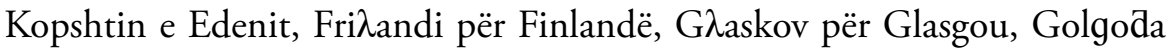
për Golgotë, hundet $\varepsilon$ Cpreses se-mire për Kepi i Shpresës së Mirë, Magenti për Mainz, Пaduene për Padova, Пatmo për Patmos, Пratєz për Prater etj.

Ashtu sikurse u parashtrua në fillim, këta libra kanë shërbyer edhe për ndriçimin shpirtëror të kombit tonë, përmes tyre marrim edhe të dhëna për shkrimin e shenjtë të botuar/përkthyer në shqip, si: Karta mbë Efesianët (ose me shkurtim Ef.) për Efesianëve/Letra Drejtuar Efesianëve, Të Dalëtë (ose me shkurtim Të dal.) për Eksodin, Ioan ose dhe Joan për Gjonin, Angjeu për Hagain, Karta e Pavlit mbë Ebrenjt për Hebrenjve/Letra dërguar Hebrenjve, Karta e Pavlit mbë Kollosianët (ose me shkurtim Kollos.) për Kolosianëvel Letra drejtuar Kolosianëve, Korinthianët ose Karta e Pavlit mbë Korinthianët për Korintasve (I dhe II), Mark. (përdoret me shkurtim) për Marku/Ungjilli 


\section{Albanon}

\section{Revistë kulturore}

sipas Markut, Ungjilli pas Mattheut/Mattheu (ose me shkurtim Matth.) për Ungjilli sipas Mateut /Mateu, Psalltiri (ose me shkurtim Ps.) për Psalmet (në toskërisht, përkthyer nga Konstandin Kristoforidhi), Karta e Pavlit mbë Romanët ose Romanëve, ose me shkurtim Rom. për Romakëve/Letra Drejtuar Romakëve, Karta e Pavlit mbë Timothenë (I dhe II) ose me shkurtim Tim. për Timoteu/Letra e Parë Drejtuar Timoteut, Punët/Punët e apostujve (ose me shkurtim Pun.) për Veprat/Veprat e apostujve, Sbulesët (ose me shkurtim Sbul.) për Zbulesa, Vivll:(ë), - a për Bibl:(ë), a, Kartë e Shenjtëruar Përdoret për shkrimin e shenjtë etj.

I parë nën optikën e sotme, Hristomathi (1902, 1907), i botuar përgjatë Rilindjes Kombëtare Shqiptare, sot shkakton vështirësi në të lexuar, jo vetëm se i takon një shqipeje mbi njëshekullore, por edhe se këto tekste u botuan përpara unifikimit të alfabetit shqip, me alfabetin e Komitetit të Stambollit. Por një lajm i mrekullueshëm na vjen për lexuesit e studiuesit nga Instituti për Studime Shqiptare dhe Protestante, i cili, nën udhëheqjen e drejtorit ekzekutiv të tij, dr. David Hosaflook, ka ndërmarrë ribotimin e tyre në shqipen e sotme. Posaçërisht, z. Hosaflook i shpreh mirënjohje vetjake që ma besoi këtë projekt, jo vetëm për vlerat e mëdha që mbart në fushën e letrave shqipe, por sidomos për përgjegjshmërinë që duhet treguar në botime të tilla, për ta ruajtur deri në rigorozitet tekstin origjinal. Fillimisht, Instituti vendosi të sjellë në alfabetin e në shqipen e sotme vetëm vëllimin II, duke marrë të mirëqenë faktin se vëllimi I u botua më $1991^{6}$, ndërsa vëllimi II nuk e njohu një botim me alfabetin e unifikuar. Pasi puna për vëllimin e dytë kishte përfunduar, u vendos që lexuesit t'i shkonin në dorë të dyja vëllimet, njëkohësisht e njëtrajtshmërisht, pasi ky projekt nuk kërkonte ripërtëritjen e botimit të dytë, por mbështetjen në tekstin burimor. Një vendim i tillë u mor edhe për dy arsye të tjera: së pari, botimi i vitit 1991 na rezulton të ketë disa mospërputhje me origjinalin, dhe $s \ddot{e}$ dyti, ky botim vështirë të gjendet në ditët e sotme, përveç ekzemplarëve të bibliotekave. Kësisoj, me ribotimin e tyre, vëllimi I përbën botimin e tretë (1902, 1991, 2019[?]2020), ndërsa

6 Qiriazi, Gjerasim. KRISTOMACI, me katër pjesë, I Vjersha II Këngë III Dialogë IV Përralla - gjëra të ndryshme e të vegjëtuara për këndim dhe për dobi të mësonjëtoreve shqipe a udhëheqës për çdo shtëpi shqiptari - të gatuara edhe një pjesë nga dialogët të kthyera prej një Mëmëdhetari, përgatiti për shtyp në grafinë e drejtshkrimin e shqipes së sotme letrare Vehap Shita, "Ilyricum”, Zagreb, "Rilindja”, Prishtinë, 1991 
vëllimi II përbën botimin e dytë (1907, 2019[?]2020), ky i fundit duke ardhur për herë të parë në alfabetin e njësuar e në shqipen standarde.

Këta faktorë na bindën se duhet t'i përpunonim dhe t'i ribotonim këta libra, duke punuar në bazë të origjinalit, si dhe duke i pasuruar tekstet me shënime të reja, fjalorthë, tabela shpjeguese etj., për t’u dhënë lexueve dhe studiuesve çelësa leximi e interpretimi. Një nga parimet kryesore të punës filologjike, për riprodhimin e një teksti, mbetet ruajtja besnike e origjinalit. Duke qenë në dijeni të këtij parimi tepër të rëndësishëm shkencor, theksojmë qysh në krye të herës, se ky ribotim nuk synon të ruajë përpikmërish origjinalin, pra nuk kemi synuar të botojmë një tekst Lorem Ipsum, që në thelb të mbetet i pandryshueshëm. Kësisoj u pa e udhës që të mos sjellim thjesht një variant të transliteruar (librat janë në fazën e tyre për botim), por tekste në shqipen e sotme, të lehta për t'u lexuar, për t'u kuptuar po edhe për t'u shfrytëzuar. Pa dyshim, ndryshimet nuk kanë prekur rrafshin semantik, por kryesisht rrafshin leksikor (arkaizmat, dialektizmat, standardizimin gjuhësor), duke bërë disa ndryshime të qëllimshme, në mënyrë që ky botim mos t'u drejtohet vetëm lexuesve të specializuar, por edhe lexuesve të thjeshtë, thënë ndryshe, kemi kërkuar që tekstet të jenë të kuptueshme nga të gjithë. Të interesuarit ndaj tekstit origjinal, shkruar me "alfabetin e Stambollit", mund ta disponojnë në bibliotekat përkatëse ose t’i drejtohen ISSHP-së për ndihmë.
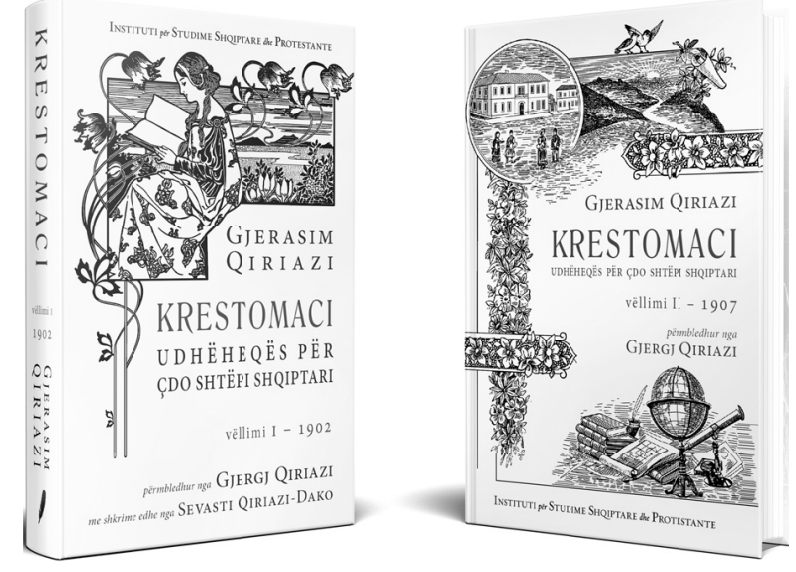

Ballinat e botimeve të reja (në proces), sjellë në shqipen e sotme nga Jorina Kryeziu (Shkreta)

Përdorur me leje të Institutit për Studime Shqiptare dhe Protestante 